\title{
Predictors of in-hospital adverse outcomes in aortic surgery
}

\author{
M Sales, C Aguzzoli, A Rösler, E Lúcio, P Leães, V Lima, M Pontes, F Lucchese \\ From 23rd World Congress of the World Society of Cardio-Thoracic Surgeons \\ Split, Croatia. 12-15 September 2013
}

\section{Background}

Aortic surgery is associated with high rates of death and complications. Our aim was to describe short-term outcomes after aortic surgery, and to identify predictors of adverse in-hospital outcomes.

\section{Methods}

All patients operated on for aortic diseases (2009-2012) were included. We evaluated demographic, clinical and operative variables, in-hospital mortality and MACCE.

\section{Results}

We included 235 pts (61 $\pm 13 y$, 66\%male). Group 1 (aneurysms 61\%) and Group 2 (dissections, ulcer, hematoma 36\%). Others: $3 \%$. Procedures: aortic root replacement $(26,5 \%)$, Bentall procedure (23,5\%), endovascular (28\%), hybrid surgery (19\%), aortoplasty and Tirone (3\%); concomitant procedures in $20 \%$ of cases. Group 2 had higher $\mathrm{BP}$, more urgent and hybrid procedures, greater pump/ ischemia time, smaller aortic size and less Bentall procedure. Mortality was 8,5\% (Group 1, 4,6\%; Group 2, 15,5\%, $\mathrm{p}=0,004$ ). Rate of MACCE was 19,2\% (Group 1, 11,3\%; Group 2, 33,7\%, p < 0,001). Reoperation occurred in $7,3 \%$, complications $34,2 \%$, stroke $4,3 \%$, AKIN 7,3\%, respiratory complications $15,9 \%$. Medullary ischemia developed in 2 patients $(0,8 \%)$. By multivariate logistic regression, independent predictors of death were hybrid procedure [OR $=7,51(1,05-53,4) \mathrm{p}=0,044]$, aortic size [OR $=1,05(1,02-1,10) \mathrm{p}=0,005]$ and pump time [OR=1,10 $(1,01-1,20) \mathrm{p}=0,034]$; predictors of MACCE were urgent surgery [OR $=7,17(1,10-49,5) \mathrm{p}=0,045]$, combined aneurysms $[22,4(1,42-353) \mathrm{p}=0,027]$, and concomitant mitral valve surgery $[O R=46,5(1,3-166) p=$ $0,035]$. Endovascular procedure was independently

\footnotetext{
* Correspondence: alvaromrosler@gmail.com

Cardiovascular Surgery, Hospital São Francisco, Porto Alegre, Brazil
}

associated with reduction of MACCE incidence [OR = $0,05(0,004-0,730) \mathrm{p}=0,045]$.

\section{Conclusions}

Aortic surgery in a specialized center is associated with low rates of in-hospital death and MACCE. Independent predictors of in-hospital death were the hybrid approach, aortic size and bypass time; predictors of MACCE included urgent surgery, combined aneurisms and concomitant mitral surgery. Endovascular approach independently reduced MACCE.

Published: 11 September 2013

doi:10.1186/1749-8090-8-S1-037

Cite this article as: Sales et al:: Predictors of in-hospital adverse outcomes in aortic surgery. Journal of Cardiothoracic Surgery 2013 8(Suppl 1):O37.
Submit your next manuscript to BioMed Central and take full advantage of:

- Convenient online submission

- Thorough peer review

- No space constraints or color figure charges

- Immediate publication on acceptance

- Inclusion in PubMed, CAS, Scopus and Google Scholar

- Research which is freely available for redistribution
() Bïomed Central

\section{Biomed Central}

(c) 2013 Sales et al; licensee BioMed Central Ltd. This is an Open Access article distributed under the terms of the Creative Commons Attribution License (http://creativecommons.org/licenses/by/2.0), which permits unrestricted use, distribution, and reproduction in any medium, provided the original work is properly cited. 